\title{
Claes Cnattingius
}

Claes Cnattingius, honorary member of IASA, died in Stockholm on March 6, 2018.

Claes was one of the archivists who established IASA in 1969 in Amsterdam. He joined the first Executive Board as Treasurer under the leadership of Donald Leavitt and held that function when in 1972 Timothy Eckersley became President. It was amongst others thanks to his work that the young Association grew steadily. In 1975 Claes left the Executive Board but that was not the end of his services to IASA.

In that first period of IASA it was also in particular thanks to him that the cooperation with the International Association of Music Libraries (IAML) went well to the benefit of both organizations. When in 1978 IAML and IASA established a Joint Committee on Music and Archives, Claes took the chair with Derek Lewis, Ulf Scharlau, Marie-France Calas, and Ann Briegleb as members. At the Annual Meetings the themes and discussions of the Joint Committee proved to be of particular interest, including in 1979

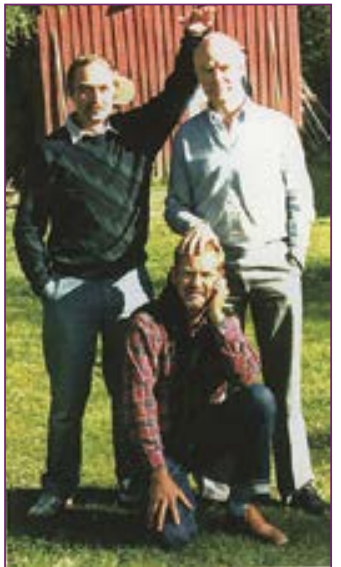

Claes in the center with Ulf (I.) and Rolf in Swedish Woods. in Salzburg "Sound Recordings in Musicological Research", in Cambridge in 1980 "Access to Radio and Record Industry Libraries", in Budapest in 1981 "Bartók's Legacy: Documentation and Dissemination of Folk Music in Sound Archives" and finally in Arlington (1983) "Popular Music in Sound Archives: Criteria for Selection and Classification". With such themes Claes and his fellow members broke ground.

1984 was the end of Claes' functions in IASA, but not of his activities. In I 986 together with Swedish colleagues he organized the Annual Conference of IAML and IASA in Stockholm. Prior to his conference, he and his wife Katarina invited a few IASA friends and their spouses for a week in the middle of the Swedish woods - an unforgettable experience. Then, in 1989, at a small festive occasion at the Oxford Conference, Claes said farewell to his friends. We met him and Katarina for the last time at the Helsinki Conference in 1993 when they came over for a short visit. Since then we kept contact via telephone and Christmas cards.

Claes was a highly professional head of the Swedish Broadcasting Archives and at the same time a highly knowledgable musicologist and music historian. He was an interesting and gentle man with a wonderful sense of humor and esprit. Above all he was a dear friend. We ourselves and all of us in IASA have a lot to thank him for.

Rolf Schuursma

IASA President (1978-198I)

Ulf Scharlau

IASA President (1984-1987) 